\title{
E-waste Generation from Mobile Phone and its Recovery Potential in Bangladesh
}

\author{
Q. San*, C. Muntaha and M. M. Hossain \\ Institute of Forestry and Environmental Sciences, \\ University of Chittagong, Chittagong-4331 \\ *Corresponding Author: quocksan@gmail.com
}

\begin{abstract}
Waste from Electrical and Electronic Equipment (WEEE) or Electronic Waste (E-waste) comes under a special category of waste which is the result of industrialization and ever increasing demand of electronic products in our daily life. With increasing usage of these products waste production is also increasing and leads to continuous depletion of finite natural resources and leading us to an uncertain future. Total number of mobile phone subscribers was 116.55 million at June 2014, about $35 \%$ of the active mobile phone subscribers were account for the dual Subscriber Identity Module (SIM) mobile phone set (MPS) and total volume of this is $990 \mathrm{~m}^{3}$, cumulatively the total weight is 1125 ton. Most of the amounts of these mobile phone sets are added per year in the total waste stream of Bangladesh. Only 2-3\% of these amounts of MPS's were recycled through the informal sector and recovered some precious metals also. If we can recycled the entire amount of MPS's about $348.75 \mathrm{~kg}$ gold, $105.75 \mathrm{~kg}$ of platinum and palladium, more than 163.29 ton of aluminum and 214.32 ton of copper can be recovered. However, these can be the basis of a sustainable material recycle industry to recover materials from the end-of-life mobile phones.
\end{abstract}

Key words: E-waste, Management, Recovery, Recycle, WEEE

\section{Introduction}

The electronic and electrical industry is the largest and fastest growing manufacturing industry of the world (Radha, 2002; DIT, 2003). In order to need of new electronic products of consumers in the market, worse in quality and shorter life for many electric appliances would be happened as E-waste. It is an emerging problem as well as a business opportunity of increasing significance, given the volumes of e-waste being generated and the content of both toxic and valuable materials in them. Precious, nonrenewable resources embedded within e-waste have given rise to a global "mining" industry that operates on the economic, social and environmental logic of transforming waste into resource (Widmer et al., 2005; Williams et al., 2008). The fraction including iron, copper, aluminum, gold and other metals in e-waste is over $60 \%$, while plastics account for about $30 \%$ and the hazardous pollutants comprise only about $2.70 \%$ (Widmer et al., 2005).
Entrepreneurial activity in the recycling and recovery sector is flourishing in developing countries, where domestic markets for some Electrical and Electronic Equipment (EEE) are ever-growing (Schluep et al., 2009; SBC, 2011). At the same time, poor environmental and labor conditions and illegal transboundary movements of e-waste have led to calls for stricter international regulation of the recycling industry (BEA, 2004; IMPEL, 2006; GAO, 2008; EEA, 2009; INTERPOL, 2009; Van Erp and Huisman, 2010). Electronic waste describes discarded electrical and electronic devices. There is a lack of consensus as to whether the term should apply to recycling, reuse, recovery and refurbishing industries. Informal processing of electronic waste in developing countries may cause serious health and pollution problems, though these countries are also most likely to reuse and repair electronics.

Table 1. E-Waste types and their mass of item with estimated life cycle

\begin{tabular}{lcc}
\hline Item & Mass of Item $(\mathbf{k g})$ & Estimated Life Cycle (y) \\
\hline Air-conditioner 2 & 55 & 12 \\
Iron 3 & 1 & 10 \\
Mobile phone (MPs) 3 & 0.1 & 2 \\
Personal Computer (PCs) 1 & 25 & 3 \\
Photocopier 2 & 60 & 8 \\
Radio 3 & 2 & 10 \\
Refrigerator 3 & 35 & 10 \\
Telephone 3 & 1 & 5 \\
Television (TVs) 3 & 30 & 5 \\
Washing machine 2 & 65 & 8
\end{tabular}

(Source: Betts, 2008; Robinson, 2009; Cobbing, 2008 and Li et al., 2009)

\section{Methodology}

The sample of the study covered all of six mobile network operator those are doing telecommunications business in Bangladesh. So, the population considered as the sample of this study. This paper is organized based on both of quantitative and qualitative data collected mainly from the secondary sources. Mobile subscriber's base data collected from periodical online reports of GSM world, Trading Economics, Bangladesh Telecommunications and Regulatory Commission 
(BTRC), Association of Mobile Telecom Operators of Bangladesh (AMTOB) and also from the websites of Mobile Network Operators (MNOs). Though the usefulness of secondary data the current problem may be limited but its importance is unavoidable and the information regarding mobile phone subscriber base of MNOs in Bangladesh anyone can collect from BTRC very easily and these are authentic as a legal and authoritative body which is controlling the telecommunications sector. Again, the strategies of MNOs are visible and transparent those can be observed from market movements and MNOs offering's. Furthermore, the same data has compared among different sources and have cross checked where observes slight fraction considered as moderately higher accuracy of information.

A survey about mobile phone waste was conducted among the mobile phone sale and repairer shops of the Chittagong metropolitan areas shopping malls to know the present situation of sales and repairer shops as well as the number of mobile phones added every year as ewaste in the total waste stream of Chittagong and also in order to ensure a higher response rate, face-to-face interviews were employed for data collection. Information from shopping malls mobile phone repairers and sellers and university students was collected through questionnaires. Data were compiled and analyzed. Finally, results were shown in tabular and graphical form.

\section{Results and Discussion}

\section{a. Mobile Network Operators (MNO's) market share}

Among six MNOs 116.55 million subscribers base of mobile telecommunications sector, Grameenphone has got the highest $42.24 \%$ market share having 49.23 million subscribers base where Banglalink is the second highest $25.23 \%$ market share gainer with 29.75 million subscribers followed by Robi $20.61 \%$ market share gainer with 24.02 million subscribers, Airtel $7.33 \%$ market share gainer with 8.54 million subscribers, Teletalk $3.08 \%$ market share gainer with 3.60 million subscribers and Citycell $1.21 \%$ market share gainer with 1.42 million subscribers.

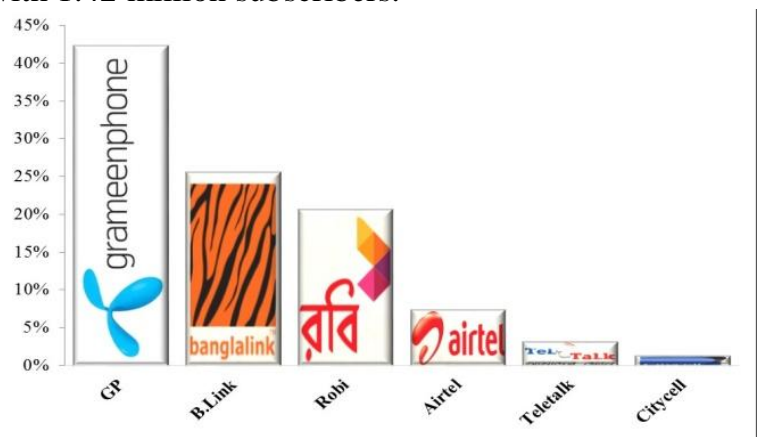

Fig. 2. MNO's Market share \% (Source: BTRC, June 2014)

\section{b. MNO's market penetration}

Market penetration is another important tool to assess life cycle position of a sector. The mobile telecommunications sector has got $70.60 \%$ market penetration i.e. 116.55 million subscriber base among 165.10 million population in Bangladesh till June, 2014. Grameenphone has got the highest penetration at $29.82 \%$ among six mobile network operators (MNOs) followed by Banglalink 18.02\%, Robi $14.55 \%$, Airtel $5.17 \%$, Teletalk $2.18 \%$ and Citycell $0.86 \%$.

\section{c. Waste stream analysis of e-waste due to mobile phone}

According to the latest statistics of Bangladesh telecommunications regulatory commission (BTRC) and Association of mobile telecom operators of Bangladesh (AMTOB) the total number of mobile phones users in the country (up to June), 11 crore 65 lakh 53 thousand with $71 \%$ mobile phone penetration in touch. But the association of mobile phone operators (AMTOB) saying, the total number of active mobile phone subscribers identity module (SIM) whatever, the total number of mobile phone subscribers is about 75.6 million utmost. Considering that only $45 \%$ of the people are now using mobile phones. AMTOB also provide these information to the national board of revenue (NBR). They also say that, mobile phone penetration in many neighboring countries is about $150 \%$ but total number of actual mobile phone users is only $100 \%$. According to AMTOB, $35 \%$ of the active mobile phone subscribers were account for the dual SIM mobile phone handset. Without them, the total number of mobile phone subscriber handset is about 7.50 million only.

1. Total volume of mobile phone sets as e-waste added per year in the total waste stream = $0.000132 \times 7500000 \mathrm{~m}^{3}=990 \mathrm{~m}^{3}$

2. Total weight of mobile phone as e-waste added per year in the total waste stream $=0.15 \mathrm{x}$ $7500000 \mathrm{Kg}=1125000.00 \mathrm{Kg}=1125.00 \mathrm{Ton}$

3. Per capita amount of mobile phone waste generation

= Total Amount of Mobile Phone Waste Generation Total Number of Population

$=(1125000 / 161000000) \mathrm{Kg}=0.00698 \mathrm{Kg}=$ $6.98 \mathrm{~g}$

Total volume of mobile phones is $990 \mathrm{~m}^{3}$, total weight of mobile phones is 1125 Ton and per capita $6.98 \mathrm{~g}$ of mobile phone waste generated per year in Bangladesh, that amount of mobile phone waste is added per year in the total waste stream of Bangladesh.

\section{d. Metal recovery potential from the PCBs of mobile phone}

The sizes of mobile phones are small and so the quantity of metals contained in each cell phone is also small. When many phones become obsolete, however, the quantity and value of the metals contained in those phones become significant. Table below shows the market value of the metals recovered from 1 ton of printed circuit boards (PCBs).

So, from 1125 ton of mobile phone wastes we can recovered about $348.75 \mathrm{~kg}$ gold, $105.75 \mathrm{~kg}$ of platinum 
and palladium, more than 163.29 ton of aluminum and

214.32 ton of copper.

Table 2. Metal recovery potential from 1 ton PCBs of mobile phone

\begin{tabular}{ll}
\hline Recovered metal & Weight $(\mathbf{k g})$ \\
\hline Precious metals (Pt, Pd) & 0.094 \\
Gold & 0.31 \\
Aluminum & 145.15 \\
Copper & 190.51 \\
\hline
\end{tabular}

\section{Conclusions}

Solid waste management itself only is already a mammoth task in Bangladesh, is becoming more complicated by the invasion of e-wastes. There subsists an urgent need for a detailed assessment of the current and future scenario including quantification, characteristics, existing disposal practices, environmental impacts etc. Establishment of e-waste recycling centers should be encouraged in public private partnership model facilities employing environmentally sound technologies and methods for recycling and recovery are to be established. Governments should encourage e-waste recycling projects under public-private partnership mode and also criteria are to be developed for recovery and disposal of e-wastes. Policy level interventions should include in the development of e-waste regulation, control of import and export of e-wastes and facilitation in development of infrastructure. An effective take-back program providing incentives for the producers to design less wasteful products which contain fewer toxic components and also easier to disassemble, reuse and recycle may help in reducing the wastes. It should set targets for e-waste collection, reuse, recycling, impose reporting requirements and include enforcement mechanisms and deposit or refund schemes to encourage consumers to return electronic devices for collection and reuse or recycling.

\section{References}

Betts, K. 2008. Producing usable materials from ewaste, Environmental Science Technology, 42: 6782-83.

BEA, 2004. Green List Waste Study. British Environment Agency (BEA) / Industry Council for Electronic Equipment Recycling. Downloaded in March 2010 from http://www.stepinitiative.org/files/step/documents/StEP_GP_Differ entiating\%20EEE\%20products\%20and\%20wastes_ 20140114.pdf.

DIT, 2003. Environmental management for Information Technology industry in India, Department of Information Technology (DIT), Government of India: 122-124.

EEA, 2009. Waste without borders in the EU? Transboundary shipments of waste, Copenhagen: European Environment Agency (EEA). Downloaded in January 2010 from http://www.eea.europa.eu/publications/wastewithout-borders-in-the-eu-transboundaryshipments- of-waste/at_download/file.
GAO, 2008. Electronic Waste: EPA Needs to Better Control Harmful US Exports through Stronger Enforcement and More Comprehensive Regulation, Washington DC: Government Accountability Office (GAO).

Downloaded in March 2010 from http://www.gao.gov/assets/280/279792.pdf.

Greenpeace, 2008. Toxic Tech: Not in Our Backyard, Uncovering the Hidden Flows of e- waste.

Report from Greenpeace International, Amsterdam. Downloaded in March 2010 from http://www.greenpeace.org/international/Global/int ernational/planet-2/report/2008/2/not-in-ourbackyard-summary.pdf.

IMPEL, 2006. IMPEL-TFS Project II: International Cooperation in Enforcement Hitting Illegal Waste Shipments, Project Report, September 2004 - May 2006. European Union Network for the Implementation and Enforcement of Environmental Law (IMPEL). Downloaded in February 2010 from https://zoek.officielebekendmakingen.nl/kst-2586814-b1.pdf.

INTERPOL, 2009. Electronic waste and organized crime-assessing the links, Phase II Report for the Interpol Pollution Crime Working Group, INTERPOL, Trends in Organized Crime. September 2009, 12(3):352-378.

Li, J. H.; Gao, S.; Duan, H. B. and Liu, L. L. 2009. Recovery of valuable materials from waste liquid crystal display panel, Waste Management, 29 : 2033-39.

Radha, G. 2002. A Study of the Performance of the South-Asian IT Sector. Retrieved on $21^{\text {st }}$ June 2010 from www.nautilus.org.

Robinson, B. 2009. E-waste: An assessment of global production and environmental impacts, Science of the Total Environment, 408:183-191.

Schluep, M.; Hagelueken, C.; Kuehr, R.; Magalini, F.; Maurer, C.; Meskers, C.; Mueller, E. and Wang, F. 2009. Recycling - from e-waste to resources, Sustainable innovation and technology transfer industrial sector studies. United Nations Environment Program and United Nations University. Paris, France: Empa, Umicore, UNU.

SBC, 2011. Where are WEEE in Africa? Findings from the Basel Convention E-waste Africa Program, Building local capacity to address the flow of ewastes and electrical and electronic products destined for re-use in selected African countries and to augment the sustainable management of resources through the recovery of materials in e- 
wastes, Secretariat of the Basel Convention (SBC). Downloaded in February 2010 from http://www.unep.fr/ozonaction/information/ mmcfiles / 7524-e-WhereareWEEEinAfrica.pdf.

Van Erp, J.; Huisman, W. 2010. Smart regulation and enforcement of illegal disposal of electronic waste (e-waste), Criminology and Public Policy, 9(3):579-590.
Widmer, R.; Oswald-Krapf, H.; Sinha-Khetriwal, D.; Schnellmann, M. and Boni, H. 2005. Global Perspectives on E-Waste, Environmental Impact Assessment Review, 25:436-458.

Williams, E.; Kahhat, R.; Allenby, B.; Kavazanjian, E. Kim, J. and Xu, M. 2008. Environmental, Social and Economic Implications of Global Reuse and Recycling of Personal Computers, Environmental Science Technology, 42:6446- 54. 